c) B. S. Hammes, D. Maldonado-Ramos, G. P. A. Yap, L. Liable-Sands, A. L. Rheingold, A. S. Borovik, Inorg. Chem. 1997, 36, 3210-3211; d) Z. Shirin, V. G. Young, A. S. Borovik, Chem. Commun. 1997, 4, $1840-1841$; e) M. Ray, B. S. Hammes, G. P. A. Yap, A. L. Rheingold, A. S. Borovik, Inorg. Chem. 1998, 37, 1527-1532.

[7] The redox potential for the $\left[\mathrm{CoH}_{3}-\mathbf{1}(\mathrm{OH})\right]^{-} /\left[\mathrm{CoH}_{3}-\mathbf{1}(\mathrm{OH})\right]^{2-}$ redox pair is comparable to that for the $\left[\mathrm{Co}(\mathrm{CN})_{6}\right]^{3-} /\left[\mathrm{Co}(\mathrm{CN})_{6}\right]^{4-}$ pair: $\mathrm{N}$. N. Greenwood, A. Earnshaw, The Chemistry of the Elements, Pergamon Press, Oxford, 1984, pp. $1302-1303$.

[8] The structure of $K_{2}-2$ has a potassium ion (K1) positioned at a distance of 2.798 (3) ^ from O1.

[9] In 2 the O1 $\cdots \mathrm{N} 5$ and O1 $\cdots \mathrm{N} 7$ distances are 2.747(4) and 2.779(4) $\AA$, while an O1 $\cdots \mathrm{N} 3$ distance of 3.019(3) $\AA$ is observed for the nonhydrogen-bonded arm.

[10] D. A. Buckingham, C R. Clark in Comprehensive Coordination Chemistry, Vol. 4 (Eds.: G. Wilkinson, R. D. Guillard, J. A. McCleverty), Pergamon Press, New York, 1987, pp. 635-900.

[11] The classical six-coordinate Werner-type complexes $\left[\mathrm{CoL}_{4}\left(\mathrm{H}_{2} \mathrm{O}\right)\right.$ $(\mathrm{OH})]^{2-}$ have been shown to be dimeric in the solids state with bridging $\mathrm{H}_{3} \mathrm{O}_{2}{ }^{-}$ligands: a) M. Ardon, A. Bino, Inorg. Chem. 1985, 24 , 1343-1347; b) M. Ardon, A. Bino, Polyhedron 1987, 6, 181 -187.

[12] A. Orlandini, L. Sacconi, Inorg. Chem. 1976, 15, 78-85.

[13] S. E. Kucharski, B. W. Skelton, A. H. White, Aust. J. Chem. 1978, 31, 47-51.

[14] Examples of paramagnetic $\mathrm{Co}^{\mathrm{III}}$ complexes with trigonal-bypyramidal stereochemistry: a) C. A. McAuliffe, S M. Godfrey, A. G. Mackie, R. G. Pritchard, Angew. Chem. 1992, 104, 932-934; Angew. Chem. Int. Ed. Engl. 1992, 31, 919-921; b) B. S. Jaynes, T. Ren, S. Liu, S. J. Lippard, J. Am. Chem. Soc. 1992, 114, 9670-9671.

[15] R. Drago, Physical Methods in Inorganic Chemistry, Saunders, Philadelphia, 1977, chap. 11.

[16] For examples relevant to $\mathrm{M}-\mathrm{OH}$ complexes in biology, see I. Bertini, C. Luchinat in Bioinorganic Chemistry (Eds.: I. Bertini, H. B. Gray, S. J. Lippard, J. S. Valentine), University Science Books, Mill Valley, 1994, pp. $37-106$.

\section{Self-Assembly of Predesigned Trimetallic Macrocycles Based on Benzimidazole as Nonlinear Bridging Motifs: Crystal Structure of a Luminescent Platinum(II) Cyclic Trimer**}

\section{Siu-Wai Lai, Michael Chi-Wang Chan,* Shie-Ming Peng, and Chi-Ming Che*}

Self-assembly of mono- and polycyclic supermolecules is a challenging yet prolific area of research. ${ }^{[1]}$ In the context of metallomacrocycles with internal cavities, efforts have focused on the design and construction of molecular squares, ${ }^{[2]}$ while triangular arrays have remained relatively unexplored. In theory, if the building blocks are sufficiently rigid, the

[*] Dr. M. C.-W. Chan, Prof. C.-M. Che, S. W. Lai

Department of Chemistry, The University of Hong Kong

Pokfulam Road, Hong Kong (China)

Fax: (+852) 28571586

E-mail: cmche@hkucc.hku.hk mcwchan@hkusub.hku.hk

Prof. S.-M. Peng

Department of Chemistry, National Taiwan University Taipei (Taiwan)

[**] We are grateful for financial support from The University of Hong Kong (and for a Postdoctoral Fellowship to M.C.W.C.) and the Hong Kong Research Grants Council. alternating combination of three subunits extending $60^{\circ}$ bite angles with three linear linkers would constitute a equilateral triangle (Scheme 1). In practice, the former is difficult to attain at metal centers but is available in a number of bidentate ligands, and thus trimeric assemblies are formed
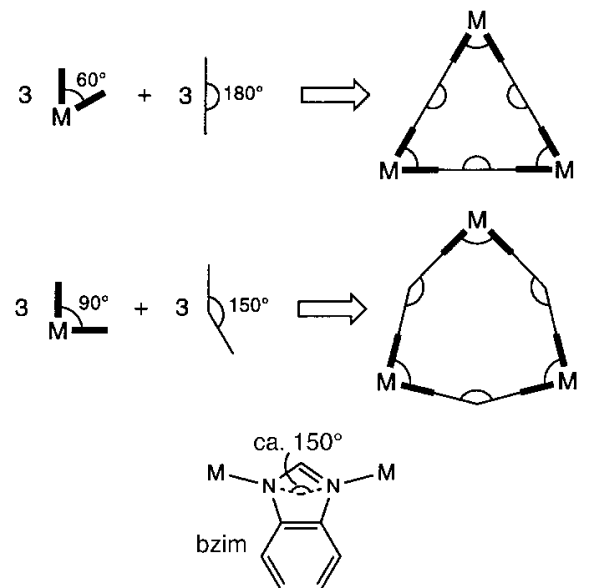

Scheme 1. Strategies for the syntheis of trimeric macrocycles with metal vertices.

in tandem with linear two-coordinate or trans-configured metallic bridges. ${ }^{[3]}$ Triangular macrocycles bearing metal vertices and supported by 4,4'-bipyridine, ${ }^{[4]} 2,2^{\prime}$-bipyrazine, ${ }^{[5]}$ 1,3-bis(1-methylbenzimidazol-2-yl)benzene, ${ }^{[6]}$ and various nucleobases $^{[7]}$ have been synthesized. However, only moderate selectivities are encountered in these reactions due to the presence of multiple chelating sites and other geometrical factors (ligand flexibility, angle strain at metal center), and mixtures of products are often afforded.

We propose a ligand-directed strategy for the fabrication of trimetallic macrocycles by using bzim $($ bzim $=\mathrm{N}$-anion of benzimidazole) as a rigid nonlinear bridging motif. Coupling of three edges exhibiting $150^{\circ}$ angles with right-angled vertices (i.e. cis binding sites at metal centers residing in square-planar and octahedral environments) is anticipated to yield a cyclic trimer, ${ }^{[8]}$ and based on this premise, the predefined geometry and unambiguous binding mode of the bidentate bzim ligand is ideal (Scheme 1). We report herein the highly efficient syntheses of luminescent platinum(II) trimeric assemblies directed by $\mathrm{N}$-deprotonated benzimidazole.

Treatment of the luminescent cyclometalated $\mathrm{Pt}^{\mathrm{II}}$ precursors $[\mathrm{Pt}(\text { thpy })(\mathrm{Hthpy}) \mathrm{Cl}]^{[9 \mathrm{a}]}\left(\mathrm{Hthpy}=2-\left(2^{\prime}\right.\right.$-thienyl $)$ pyridine $)$ and $\left[n \mathrm{Bu}_{4} \mathrm{~N}\right]\left[\mathrm{Pt} \text { (bzqn) } \mathrm{Cl}_{2}\right]^{[9 b]} \quad($ Hbzqn $=7,8$-benzoquinoline $)$ with sodium benzimidazolate afforded $[\mathrm{Pt}(\text { thpy })(\text { bzim })]_{3}(\mathbf{1})$ and $[\operatorname{Pt}(\text { bzqn })(\text { bzim })]_{3}(\mathbf{2})$ as orange and yellow crystalline solids, respectively, in high yields ( $80-90 \%)$. In the FAB mass spectra, the anticipated molecular ion clusters for $\mathbf{1}$ and $\mathbf{2}$ are observed at $\mathrm{m} / z, 1417$ and 1471, respectively. The trimeric nature of $\mathbf{1}$ was confirmed by X-ray crystallography. ${ }^{[10]}$

The molecular structure of $\mathbf{1}$ (Figure 1) consists of alternating [(thpy)Pt] vertices and benzimidazolate edges. The slightly distorted square-planar geometry around each platinum center comprises the $\mathrm{N}$ and ortho-C atoms of thpy and 


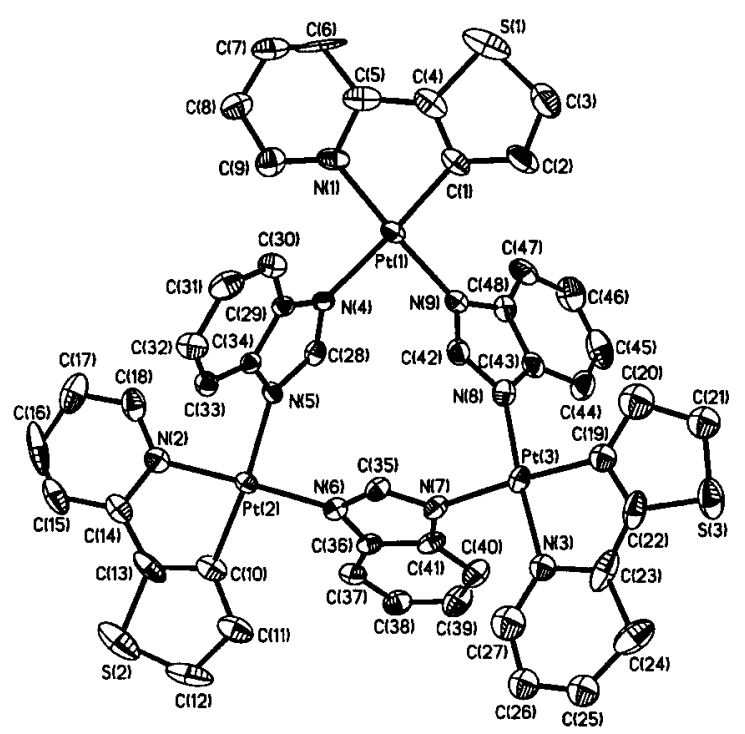

Figure 1. Perspective view of $\mathbf{1}$ (30\% probability ellipsoids. Hydrogen atoms and solvent molecules are omitted for clarity). Selected bond lengths $[\AA]$ and angles [ $\left.{ }^{\circ}\right]: \operatorname{Pt}(2)-\mathrm{N}(2) 2.03(1), \operatorname{Pt}(2)-\mathrm{C}(10) 2.01(1), \operatorname{Pt}(2)-\mathrm{N}(5)$ 2.100(9), $\mathrm{Pt}(2)-\mathrm{N}(6)$ 2.016(9), N(4) $-\mathrm{C}(28)$ 1.33(1), N(5)-C(28) 1.35(1), $\mathrm{N}(6)-\mathrm{C}(35)$ 1.34(1), $\mathrm{N}(7)-\mathrm{C}(35)$ 1.32(1), $\mathrm{N}(8)-\mathrm{C}(42)$ 1.34(1), $\mathrm{N}(9)-$ C(42) 1.33(1); N(2)-Pt(2)-C(10) 80.7(5), N(5)-Pt(2)-N(6) 89.0(3), N(7)Pt(3)-N(8) 88.4(4), N(4)-Pt(1)-N(9) 87.8(3), Pt(1)-N(4)-C(28) 130.3(7), $\mathrm{N}(4)-\mathrm{C}(28)-\mathrm{N}(5)$ 114.6(9), $\mathrm{Pt}(2)-\mathrm{N}(5)-\mathrm{C}(28)$ 132.8(8).

two $\mathrm{N}$ atoms of different bzim bridges. The comparable interatomic distances within the N-C-N fragments of the bzim moieties (mean $1.33 \AA$ ) imply considerable delocalization after $\mathrm{N}$-deprotonation. The three N-Pt-N angles within the macrocycle (range $87.8(3)-89.0(3)^{\circ}$ ) show minimal strain, in contrast to Fujita's proposed triangles containing 4,4'-bipyridine. ${ }^{[4]}$ The $\mathrm{Pt}-\mathrm{N}($ bzim) interactions are out of the triplatinum plane (Figure 2) because the bidentate bite angles

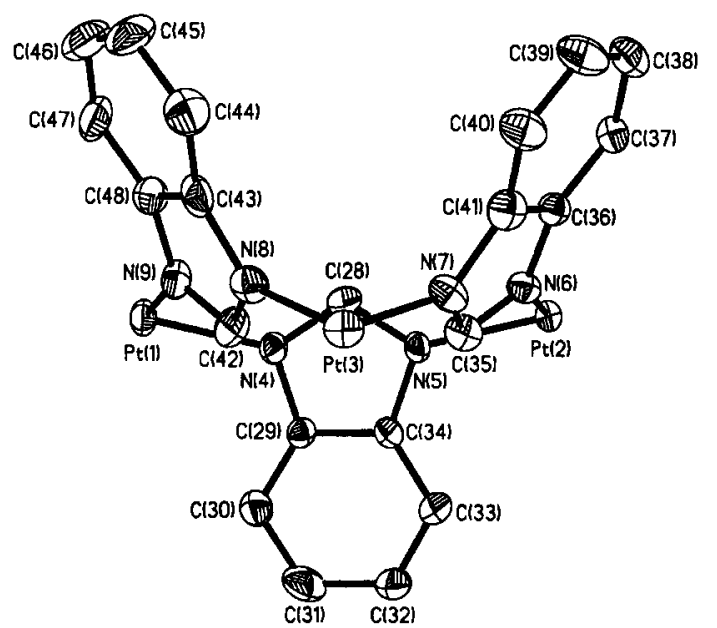

Figure 2. Perspective view of $\mathbf{1}$ showing orientations of benzimidazolate ligands (thpy groups are omitted for clarity).

exhibited by the bzim anions (range $138-140^{\circ}$ ) deviate slightly from $150^{\circ}$. This inherent coordination geometry ensures the successful and efficient assembly of the trimeric macrocycles described here. Interestingly, the bzim groups are orientated in a syn, anti, anti (two-up, one-down) fashion to create an open cavity with different faces, which is reminiscent of the partial cone conformation in calixarenes. ${ }^{[11]}$ From the mean plane through the platinum atoms, the angle to the syn bzim units is $60^{\circ}$ (av), while the inclination of the unique bzim is $77^{\circ}$. The opening at the syn bzim rim is about $7.4 \AA$, which narrows considerably towards the core to about $4.7 \AA$ at the imidazole centroids. The Pt $\cdots \mathrm{Pt}$ distances are $6.1 \AA$ (av), while the depth of the cavity is approximately $5 \AA$. This molecular pocket has lower symmetry than previously reported metallomacrocycles, ${ }^{[2 e]}$ and this may have important consequences for future work towards molecular hosts. In addition, $\pi-\pi$ interactions are evident between thpy systems in adjacent molecules, with interplanar separations of around $3.5 \AA$.

The absorption spectrum of $\mathbf{1}$ in $\mathrm{CH}_{2} \mathrm{Cl}_{2}$ contains bands at $270-360,400-430$, and $480-560 \mathrm{~nm}$, which can be assigned to spin-allowed ligand-centered ${ }^{1} \mathrm{LC}, \pi_{\text {thpy }} \rightarrow \pi_{\text {thpy }}^{*}$ with metal perturbation) and spin-allowed and spin-forbidden metal-toligand charge transfer ( ${ }^{1} \mathrm{MLCT}$ and ${ }^{3} \mathrm{MLCT}, \mathrm{d}_{\mathrm{Pt}} \rightarrow \pi_{\text {thpy }}^{*}$ ) transitions, respectively. ${ }^{[12]}$ The UV/Vis spectrum of $\mathbf{2}$ is comparable to that of the bis(cyclometalated) derivative [Pt(bzqn) $\left.)_{2}\right]{ }^{[13]}$ Complex $\mathbf{1}$ is emissive at $301 \mathrm{~K}$ in $\mathrm{CH}_{2} \mathrm{Cl}_{2}$, with peak maxima at $560(\mathrm{sh}, 580 \mathrm{~nm})$ and $606 \mathrm{~nm}$ (sh, 636 and $661 \mathrm{~nm}$; lifetime, $\tau=8 \mu \mathrm{s}$; quantum yield, $\Phi=0.016$ ) that are slightly blue-shifted to $557(\mathrm{sh}, 575 \mathrm{~nm})$ and $601 \mathrm{~nm}$ (sh, 633 and $656 \mathrm{~nm})$ at $77 \mathrm{~K}$. Based on previous studies ${ }^{[12,13]}$ and the observation of minor solvatochromic effects $(<10 \mathrm{~nm})$, these emissions are tentatively assigned as MLCT transitions with LC character. In the crystalline form, multiple emission with $\lambda_{\max }$ at 571, 617, and $664 \mathrm{~nm}$ are apparent at $301 \mathrm{~K}$. The substantial red shift of the $664 \mathrm{~nm}$ band relative to that observed in the solution state is attributed to excimeric emission arising from $\pi$-stacking in the solid state (see above). ${ }^{[14]}$ In contrast, no emission is observed for $\mathbf{2}$ in $\mathrm{CH}_{2} \mathrm{Cl}_{2}$ or in the solid state at room temperature, although weak emission is evident at $77 \mathrm{~K}$ in solid state. Hence complex $\mathbf{1}$ has greater potential for photoinduced energy and electron transfer applications than $\mathbf{2}$.

In conclusion, we have described a simple yet efficient methodology for the synthesis of trimeric platinum(II) macrocycles, which are structurally related to calixarenes. We anticipate that this strategy will be applicable to other square-planar and octahedral metal complexes. In view of the established photoluminescence of cyclometalated $\mathrm{Pt}^{\mathrm{II}}$ species, ${ }^{[15]}$ this study paves the way for the design of molecular sensors with large cavities ${ }^{[16]}$ based on suitable nonlinear bidentate ligands with rigid, predefined geometry.

\section{Experimental Section}

1: A mixture of benzimidazole $(0.05 \mathrm{~g}, 0.39 \mathrm{mmol})$ and excess $\mathrm{NaH}$ in THF $(10 \mathrm{~mL})$ under a $\mathrm{N}_{2}$ atmosphere was stirred for $20 \mathrm{~min}$ until the evolution of hydrogen ceased. The solution was filtered, added to [ $\mathrm{Pt}(\mathrm{thpy})(\mathrm{Hthpy}) \mathrm{Cl}]$ $(0.20 \mathrm{~g}, 0.36 \mathrm{mmol})$ in $\mathrm{CH}_{2} \mathrm{Cl}_{2}(15 \mathrm{~mL})$, and stirred at reflux for $12 \mathrm{~h}$. The resultant orange solution was concentrated to $5 \mathrm{~mL}$ and addition of diethyl ether afforded an orange solid. Slow evaporation of an acetone/benzene solution yielded orange crystals (yield $88 \%$ ). Satisfactory elemental analysis was obtained; ${ }^{1} \mathrm{H}$ NMR $\left(500 \mathrm{MHz}, \mathrm{CD}_{2} \mathrm{Cl}_{2}, 27^{\circ} \mathrm{C}, \mathrm{TMS}\right): \delta=$ $8.40-6.31(\mathrm{~m}) ;{ }^{13} \mathrm{C}$ NMR (126 MHz, [D $]$ DMSO, $\left.27^{\circ} \mathrm{C}, \mathrm{TMS}\right): \delta=162.6$, 150.6-148.3, 144.2-140.3, 133.3-132.7, 128.8-128.1, 123.0-115.5, 110.5; IR (Nujol): $\tilde{v}=1605 \mathrm{~cm}^{-1}(\mathrm{C}=\mathrm{N})$; UV/Vis $\left(\mathrm{CH}_{2} \mathrm{Cl}_{2}\right): \lambda_{\max }(\varepsilon)=277$ (47000), 
337 (22000), 357 (18000), 409 (5200), 421 (4800), 480 (110), 494 (110), 512 (110), 535(80), $554 \mathrm{~nm}(70)$; FAB-MS: $m / z$ (\%): 1417 (100) $\left[M^{+}\right], 1300(30)$ $\left[M^{+}-\right.$bzim $]$.

2: As for 1 using benzimidazole $(0.04 \mathrm{~g}, 0.33 \mathrm{mmol})$, excess $\mathrm{NaH}$, and $\left[n \mathrm{Bu}_{4} \mathrm{~N}\right]\left[\mathrm{Pt}(\right.$ bzqn $\left.) \mathrm{Cl}_{2}\right](0.20 \mathrm{~g}, 0.29 \mathrm{mmol})$. A yellow precipitate was afforded after reflux for $12 \mathrm{~h}$. Slow evaporation of an acetone/benzene solution yielded yellow crystals (yield $84 \%$ ). Satisfactory elemental analysis was obtained; ${ }^{1} \mathrm{H}$ NMR $\left(500 \mathrm{MHz},\left[\mathrm{D}_{6}\right] \mathrm{DMSO}, 27^{\circ} \mathrm{C}, \mathrm{TMS}\right): \delta=9.26-6.91(\mathrm{~m})$; ${ }^{13} \mathrm{C}$ NMR $\left(126 \mathrm{MHz},\left[\mathrm{D}_{6}\right] \mathrm{DMSO}, 27^{\circ} \mathrm{C}, \mathrm{TMS}\right): \delta=156.7,149.4-148.8$, 144.2-138.4, 133.4-115.7, 110.5; IR (Nujol): $\tilde{v}=1620,1610 \mathrm{~cm}^{-1}(\mathrm{C}=\mathrm{N})$; UV/Vis $\left(\mathrm{CH}_{2} \mathrm{Cl}_{2}\right): \lambda_{\max }(\varepsilon)=271(70000), 278(73000), 358$ (14000), 372 (14000), 413 (4000), $469 \mathrm{~nm}(440)$; FAB-MS: $m / z(\%): 1471(100)\left[M^{+}\right]$, $1354(25)\left[M^{+}-\right.$bzim $]$.

Received: September 16, 1998 [Z12422 IE] German version: Angew. Chem. 1999, 111, 708-710

Keywords: luminescence $\cdot$ metallomacrocycles $\cdot \mathrm{N}$ ligands • platinum $\cdot$ self-assembly

[1] a) J.-M. Lehn, Supramolecular Chemistry, VCH, Weinheim, 1995; b) V. Balzani, F. Scandola in Comprehensive Supramolecular Chemistry, Vol. 10 (Eds.: J. L. Atwood, J. E. D. Davies, D. D. Macnicol, F. Vögtle), Pergamon, Oxford, 1996, pp.687-746; c) D. Philp, J. F. Stoddart, Angew. Chem. 1996, 108, $1242-1286$; Angew. Chem. Int. Ed. Engl. 1996, 35, 1154-1196; d) J.-P. Sauvage, Acc. Chem. Res. 1990, 23, 319-327.

[2] a) M. Fujita, K. Ogura, Bull. Chem. Soc. Jpn. 1996, 69, 1471-1482; b) B. Olenyuk, A. Fechtenkötter, P. J. Stang, J. Chem. Soc. Dalton Trans. 1998, $1707-1728$; c) R. V. Slone, J. T. Hupp, C. L. Stern, T. E. Albrecht-Schmitt, Inorg. Chem. 1996, 35, 4096-4097; d) W. H. Leung, J. Y. K. Cheng, T. S. M. Hun, C. M. Che, W. T. Wong, K. K. Cheung, Organometallics 1996, 15, 1497 -1501; e) C. A. Hunter, Angew. Chem. 1995, 107, 1181-1183; Angew. Chem. Int. Ed. Engl. 1995, 34, 10791081.

[3] For example, see: a) H. H. Murray, R. G. Raptis, J. P. Fackler, Jr., Inorg. Chem. 1988, 27, 26-33; b) J. R. Hall, S. L. Loeb, G. K. H. Shimizu, G. P. A. Yap, Angew. Chem. 1998, 110, 130-133; Angew. Chem. Int. Ed. 1998, 37, 121-123.

[4] M. Fujita, O. Sasaki, T. Mitsuhashi, T. Fujita, J. Yazaki, K. Yamaguchi, K. Ogura, Chem. Commun. 1996, 1535-1536.

[5] R.-D. Schnebeck, L. Randaccio, E. Zangrando, B. Lippert, Angew. Chem. 1998, 110, 128-130; Angew. Chem. Int. Ed. 1998, 37, 119-121.

[6] a) R. F. Carina, A. F. Williams, G. Bernardinelli, J. Organomet. Chem. 1997, 548, 45-48; b) S. Rüttimann, G. Bernardinelli, A. F. Williams, Angew. Chem. 1993, 105, 432-434; Angew. Chem. Int. Ed. Engl. 1993, 32, $392-394$.

[7] a) H. Chen, M. M. Olmstead, D. P. Smith, M. F. Maestre, R. H. Fish, Angew. Chem. 1995, 107, 1590-1593; Angew. Chem. Int. Ed. Engl. 1995, 34, 1514-1517; b) D. P. Smith, E. Baralt, B. Morales, M. M. Olmstead, M. F. Maestre, R. H. Fish, J. Am. Chem. Soc. 1992, 114, $10647-10649$

[8] The crystal structure of an imidazolate-bridged trinuclear copper(II) complex has been published: P. Chaudhuri, I. Karpenstein, M. Winter, C. Butzlaff, E. Bill, A. X. Trautwein, U. Flörke, H.-J. Haupt, J. Chem. Soc. Chem. Commun. 1992, 321-322.

[9] Prepared by modification of published procedures: a) T. J. Giordano, P. G. Rasmussen, Inorg. Chem. 1975, 14, 1628-1634; b) C. A. Craig, F. O. Garces, R. J. Watts, R. Palmans, A. J. Franks, Coord. Chem. Rev. 1990, 97, 193-208.

[10] Crystal structure data for 1: $\mathrm{C}_{48} \mathrm{H}_{33} \mathrm{~N}_{9} \mathrm{Pt}_{3} \mathrm{~S}_{3} \cdot 1.5 \mathrm{C}_{6} \mathrm{H}_{6} ; M_{\mathrm{r}}=1534.47$, triclinic, $P \overline{1}, a=14.2225(2), \quad b=15.1095(1), c=16.0380(2) \AA, a=$ 62.936(1), $\quad \beta=70.543(1), \quad \gamma=71.802(1)^{\circ}, \quad V=2840.3(1) \AA^{3}, \quad Z=2$, $\rho_{\text {calcd }}=1.794 \mathrm{~g} \mathrm{~cm}^{-3}, \quad \mu=7.524 \mathrm{~mm}^{-1}, \quad F(000)=1458, \quad \lambda\left(\mathrm{Mo}_{\mathrm{K} \alpha}\right)=$ $0.71073 \AA$ Å $T=295 \mathrm{~K}$. Orange crystal, dimensions $0.15 \times 0.10 \times$ $0.08 \mathrm{~mm}^{3}$. A total of 9954 unique reflections $\left(R_{\mathrm{int}}=0.096\right)$ were collected on a Siemens SMART CCD diffractometer $\left(\omega\right.$ scans, $2 \theta_{\max }=$ $50^{\circ}$ ). The structure was solved by direct methods and refined by leastsquares treatment on $F^{2}$ using the SHELXL-93 program: $R=0.051$, $w R=0.109, \mathrm{GOF}=0.947$ for 6219 absorption-corrected (Sadabs, transmission $0.35-0.58)$ reflections with $I>2 \sigma(I)$ and 570 parameters. The 2-(2'-thienyl)pyridine group chelated to $\mathrm{Pt}(3)$ is disordered with 33: $67 \%$ occupancy. Crystallographic data (excluding structure factors) for the structures reported in this paper have been deposited with the Cambridge Crystallographic Data Center as supplementary publication no. CCDC-102975. Copies of the data can be obtained free of charge on application to CCDC, 12 Union Road, Cambridge CB21EZ, UK (fax: (+44)1223-336-033; e-mail: deposit@ccdc.cam. ac.uk).

[11] C. D. Gutsche, Calixarenes, Royal Society of Chemistry, Cambridge, 1989. A related tetranuclear platinum-incorporated analogue of calix[4]arene $\left.[\{\mathrm{Pt}(\mathrm{en}) \text { (uracilate })\}_{4}\right]^{4+}(\mathrm{en}=1,2$-diaminoethane $)$ has been reported: H. Rauter, E. C. Hillgeris, A. Erxleben, B. Lippert, J. Am. Chem. Soc. 1994, 116, 616-624.

[12] P-I. Kvam, M. V. Puzyk, V. S. Cotlyr, K. P. Balashev, J. Songstad, Acta Chem. Scand. 1995, 49, 645-652.

[13] M. Maestri, D. Sandrini, V. Balzani, L. Chassot, P. Jolliet, A. von Zelewsky, Chem. Phys. Lett. 1985, 122, 375-379.

[14] V. H. Houlding, V. M. Miskowski, Coord. Chem. Rev. 1991, 111, 145 152.

[15] a) C. W. Chan, T. F. Lai, C. M. Che, S. M. Peng, J. Am. Chem. Soc. 1993, 115, $11245-11253$; b) T. C. Cheung, K. K. Cheung, S. M. Peng, C. M. Che, J. Chem. Soc. Dalton Trans. 1996, $1645-1651 ;$ c) H. Q. Liu, T. C. Cheung, C. M. Che, Chem. Commun. 1996, 1039-1040; d) L. Z. Wu, T. C. Cheung, C. M. Che, K. K. Cheung, M. H. W. Lam, Chem. Commun. 1998, 1127-1128.

[16] A. P. de Silva, H. Q. N. Gunaratne, T. Gunnlaugsson, A. J. M. Huxley, C. P. McCoy, J. T. Rademacher, T. E. Rice, Chem. Rev. 1997, 97, 15151566.

\section{A New Type of Glycosidic Linkage: An Open- Chain Acetal-Linked $N$-Acetylgalactosamine in the Core Part of the Lipopolysaccharides from Proteus Microorganisms**}

\section{Evgeny Vinogradov and Klaus Bock*}

Monosaccharides in natural compounds are usually present in a cyclic hemiacetal form, in which the exocyclic hemiacetal oxygen atom is used for the connection to the aglycon. Herein we report the identification of a new type of linkage between monosaccharides found in the core part of the lipopolysaccharides (LPS) from two serotypes of Proteus. LPS is a component of the outer membrane of Gram-negative bacteria, and comprises three regions: the $\mathrm{O}$-antigenic polysaccharide, the lipid A, and the core, a nonrepetitive oligosaccharide linking the $\mathrm{O}$-antigenic polysaccharide to the lipid A. ${ }^{[1]}$ Normally, core oligosaccharides have complex structures, relatively conserved for each type of bacteria. The biological

[*] Prof. K. Bock, E. Vinogradov

Carlsberg Laboratory, Department of Chemistry

Gamle Carlsberg Vej 10, DK-2500 Copenhagen (Denmark)

Fax: (+45)3327-4708

E-mail: kbo@crc.dk

[**] We thank Prof. Dr. W. Kaca, Prof. Dr. Z.Sidorczyk, and Prof. Dr A.Rozalski from The Institute of Microbiology \& Immunology of University of Lodz, Lodz, Poland, and Prof. Dr. E. S. Stanislavsky from I. I. Mechnikov Institute of Vaccine and Sera, Russian Academy of Medical Sciences, Moscow, Russia for supplying bacterial cells, and Dr. Jens $\varnothing$. Duus for helpful discussions. 